\title{
Evolution of the term 'race' in legal discourse practices
}

\author{
O. A. Krapivkina \\ Institute of Linguistics and Cross-Cultural Communication \\ Irkutsk National Research Technical University \\ Irkutsk, Russia \\ Koa1504@mail.ru
}

\begin{abstract}
The article describes discourse practices as transforming verbal activities. The research aims to analyze their evolution as a result of the dynamic transition from the concept to the notion and term. The novelty of the article is due to the study of discourse practices through semiotic entities (concept, notion and term) which helps follow their evolution in legal settings. The evolution of discourse practices was analyzed by studying the term 'race' in legal texts. Evolution of discourse practices is described as follows: 1) at the first stage, there is a dispersion of features and no unified nomination (Discourse of Differences); at the second stage, the semiotic entity acquires a nomination as a result of negotiating features (Discourse of Concord); at the third stage, the semiotic entity evolves into the term (Discourse of Expert Community). The article emphasizes that in modern semiosis, knowledge can develop other term compared to the described above - the term can evolve into the notion or the notion can evolve into the concept. Linguistic and semiotic analysis of evolution of legal discourse practices helped to identify a promising research field - a dialectical transformation of knowledge from the term into the notion or from the notion into the concept.
\end{abstract}

Keywords-discourse practices, Discourse of Differences, Discourse of Concord, Discourse of Expert.

\section{INTRODUCTION}

Henceforward the concept of discourse practice refers to traditions of linguistic and semiotic communication activities of a discourse community which are based on specific cultural values. Discourses are a part and parcel of discourse practices. They form a frame of discourse formations, structuring the reality in a definite manner and being related to a certain historical period [1]. Each historical period or era causes the evolution of discourse practices as far as it brings about changes in perception of the reality, social intentionality and mentality; plants new social values. Legal discourse is sensitive to transformations as well: it cannot exist independently of the social reality where the semiosis takes place.

Social, political and cultural changes, events, which form new social and cultural eras and new time of culture, transform conventional ways of conceptualization of law and legal reality in discourse practices. Social, political and cultural transformations cause changes in names, documentation techniques, text formation rules, concepts, around which legal discourse centers.
The paper suggests that discourse practices are based on the dynamic transition from the concept to the notion and the term, and depend upon socialization of viewpoints of communicants [2, p. 117]. The evolution of discourse practices is the result of changes in the semiosis structure characterizing any given historical era in terms of social intentionality. That structure is referred to as a time of culture - a period of semiotic rules determined by characteristics of the social and cultural era [1, p. 71-83].

\section{DISCOURSE PRACTICES AS FORMS OF SOCIAL INTERACTION}

According to the knowledge evolution theory suggested by A. Kaplunenko, discourse practices pass through three stages in their evolutionary development: Discourse of Differences, Discourse of Concord, and Discourse of Expert Community. The concept, the notion and the term can be referred to as homeostasis of discourse practices in their evolutionary development.

At the first stage, discourse practice based on phenomenological knowledge and individual experience can be referred to as Discourse of Differences which is a semiotic interaction where an individual context of interpretation is predominant. Discourse is organized around concepts which represent empirical knowledge involved in individual experience [3].

Concepts are the basis form Discourse of Differences, as they have a phenomenological nature. The latter causes individual interpretations based on the experience and existing knowledge.

The relation between a significatum and a significant of the sign are unstable due to the unlimited scope of features. Confrontation of opinions is a process that is similar to military actions that may result either in reconciliation of opinions or in entire misunderstanding.

Discourse of Differences as a form of discourse practices has been known from the time of ancient thinkers. It is nothing else but disputes, - an opposition of mixed views. Since then, people have been trying to find the truth, which sometimes comes as a result of a dispute. In disputes, they discussed critical issues, developed their ideas on the premise that individuals can have contrary opinions about one and the same thing, so each communicant took a stand. It is assumed that Protagoras was the first who used that method. 
Antique public disputes are a typical example of a conflict of different points of view. Their core can be represented with Protagoras' statement: "Man is the measure of all things" [4, p. 203]. The statement is interpreted to mean that there are no objective, absolute standards that are external to human beings. Instead, all standards by which things might be measured (including human values) must come from within human beings and depend upon the circumstances and situations. Protagoras' notion that judgments and knowledge are in some way related to the person judging or knowing has been very influential.

In ancient public disputes, everyone can have antinomic views. They were based on opinions and beliefs rather than on the truth and knowledge.

The disputes were taken to the next stage in medieval universities where scholasticism was going strong. Ideas of dual world views encouraged debates on different theological issues. Later, theological issues were succeeded by scientific ones being one of the methods of searching for the absolute truth in the objective world.

However, Discourse of Differences is not an absolute conflict and global misunderstanding. It is a process of identification of universal features. Antique thinkers said that truth is born in disputes. It is nothing else but movement to the universal. When communicants claim their features to be considered as the only possible, they attempt to conciliate different opinions and find a rational universal.

That method of conflict resolution was used in antique legal settings as well. The Ancient Romans and Greeks had arbitration systems (a form of alternative private legal dispute resolution by an independent arbiter). The Romans addressed to an independent judge appointed by disputants. Disputants stated their controversial opinions on question matters, and the arbiter delivered a compromise decision. The arbitration procedure in Athens was described by Aristotle: "If the parties cannot resolve their dispute, the task of the arbitral tribunal is to resolve it for them by making a decision. If both parties are satisfied with the decision and agree on it, a dispute is considered settled" [5, p. 271].

Discourse of Differences is related to the phenomenon of intentionality and phenomenological component. Different views are due to the subjective cognition of the world. As a result, the phenomenological meaning is individual sign interpretation which is based on personal interaction of an individual with signs of a semiotic sphere. Multiple interpretations of reality in Discourse of Differences enable one to form situations for constructing particular reality when presentation and perception of reality is inherent in its evaluation. At this stage, there is a common area on the intentional horizon, but there are no accepted nomination units [6, p. 20].

Discourse of Differences can appear in any historical period including contemporary postmodern era where one can observe different opinions and lack of a single interpretative vector, which probably leads to the beginning of simulacrum development and clashes.
Establishment of the rationalism principle as a manifestation of knowledge, science and technology progress gave rise to Discourse of Concord when participants attempt to achieve consensus or compromise. European rationalism giving up on scholastic speculation methods addressed the issue of scientific knowledge basis attempting to prove that reason is the only reliable source. The idea was declared by Bacon in his statement Knowledge itself is power. For Bacon, acquiring new knowledge is directly related to the automatic transition from private knowledge (axioms) to more general one. Proponents of rationalism eliminated emotions, personal views when making scientific decisions. Rationalist thinking is referred to as a notional activity because operating with notions enables science to perform its main cognitive functions: description, explanation and prediction of phenomena. For this very reason, each science has its own language. Fundamental requirement of classical rationalism is to find absolute truth having general meaning for any human mind. This approach does not involve dispersion of interpretations typical of Discourse of Differences where everyone maintains their own truth.

Transition from Discourse of Differences to Discourse of Concord can be compared with the scientific revolution described by T. Kuhn [7]. Kuhn outlined a revolutionary model of scientific change. Kuhn's conception of scientific change occurring through revolutions undermined the traditional scientific goal, finding "truth" in nature. Kuhn's notion of scientific progress rested upon his concept of a paradigm: the common terminology and basic theories of a scientific community and that community's fundamental assumptions about methodology and what questions a scientist can legitimately ask. Kuhn thus argued against the notion of science as an activity approximating more and more closely the truth in nature. With his suggestion that human beings are forever separate from truth, Kuhn implied that truth does not guide science. In the pre-paradigm phase of sciences, Kuhn argues, there is no consensus on any particular theory. This phase is characterized by several incompatible and incomplete theories. Isn't this similar to Discourse of Differences? Scientists who investigated one and the same objects could not come to a consensus for their nature because they described similar objects with different names and descriptions. Lack of consensus exists as long as there is no theory supported by most of scientists in the field. It is a phase of normal science characterized by consensus within the discipline. The theory becomes a paradigm.

When building consensus, scientists develop a notion of the object under study, choose a language sign which would nominate it. "Notions are entities which people agree upon, constructed in order to have common language when debating" [8, p. 5].

Notions have a number of characteristics selected from concepts and negotiated by communicants. A limited number of characteristics of the concept encourages consensus and concord of different views which is an indicator of Discourse of Concord. By limiting individual characteristics, individual interpretants of Discourse of Differences give way to a single interpretant. Limitation of characteristics helps to encourage 
cooperation in perceiving deeper, implicit characteristics of the object.

Thus, Discourse of Concord is a stage of overcoming differences in knowledge and accepting a united nomination [2, p. 20-21]. A notion as a basis for Discourse of Concord can be presented in a Venn diagram, where A is characteristics which the first communicant attributes to the object; $\mathrm{B}$ is characteristics which the second communicant attributes to the object; the intersection area is a limited number of characteristics which were selected from concepts as a result of negotiations. (fig.1).

Discourse of Expert Community (DEC) is the next stage of evolution of discourse practices. It involves forming terminology which helps to differentiate between experts and laymen. Participants of expert communities have special knowledge for handling professional issues, generating expert opinions and ideas using professional terminology. The term serves as a specialized limiting nomination of objects, phenomena, their properties and relations in certain professional settings. As Florensky put it, the term is a limit of the area of culture. It belongs to that culture being its limit, boundary, border of a thought [9]. If the phenomenological nature of the concept results in communication failure, multiple interpretants of the sign, the term has a limited number of characteristics, reducing the likelihood of different interpretations.

Joining DES, the subject adopts professional language, demonstrates his/her expertise, shows that knowledge is not available for layperson. Interpretation of professional phenomena is expert conceptualization based on expertise and terminology rather than on phenomenological experience. Communication failure is not typical for DES as the term is defined with a set of characteristics which is common for each communicant.

Thus, the evolution of discourse practices can be described as follows: at the first stage, the semiotic entity has multiple phenomenological characteristics and lacks a united nomination (Discourse of Differences); at the second stage, overcoming differences in knowledge encourage formation of a united nomination (Discourse of Concord); at the final stage, the semiotic entity acquires characteristics which are relevant for a specific expert community (Discourse of Expert Community) (see Figure 2).

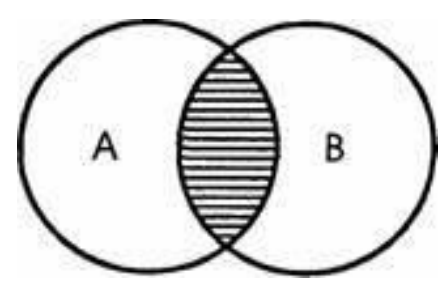

Fig. 1. Formation of a notion

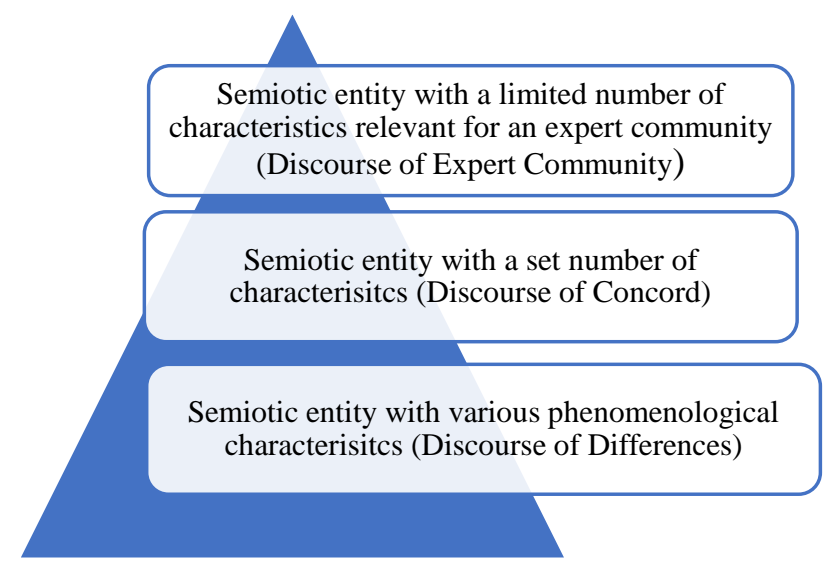

Fig. 2. Evolution of discourse practices

\section{EVOLUTION OF THE SIGN IN LEGAL DISCOURSE PRACTICES}

To illustrate aforesaid, let us analyze the contexts of the name race in American legal discourse of XVIII-XXI centuries. Analysis of knowledge forms in a historical context helps follow evolutionary development of legal discourse practices.

Hoffman says that the word race is omnipresent in American social, political, and legal discourse [8]. It is central to contemporary debate about racial profiling, hate crimes, health inequities, and many other issues. That debate began as early as the first half of the XX century. In the 1930s, Barzun wrote that "among the words that can be all things to all men, the word race has a fair claim to being the most common, the most ambiguous, and the most explosive. No one today would deny that it is one of the great catchwords about which ink and blood are everywhere spilled in reckless." [10]

According to one authority, in 1684 a French traveler and physician, Francois Bernier, was the first to use the term race to describe human beings by skin color and appearance [11]. According to another source, race was first utilized in natural history literature in 1749 by Georges Louis Leclerc to categorize groups of people [12].

For the last three centuries, the concept of race was used in various contexts: to describe a biological feature, a local geographic population, a group linked by common descent or origin, a population connected by a shared history, nationality, or geographic distribution, a subspecies, and a social and political construct.

The question of whether race is a meaningful or useful concept has long been disputed among scholars in a number of disciplines, including anthropology, sociology, psychology, epidemiology, and public health [13, p. 1109].

In American legal discourse, the concept of race initially lacked a united nomination being verbalized with different names and descriptions emphasizing phenomenological characteristics of communicants which is typical for Discourse of Differences, for example: 
... if any negro or mulatto shall presume to smite or strike any person of the English or other Christian nation, such negro or mulatto shall be severely whipped...... (Act for the better preventing of a spurious and mixed issue, 1705) ${ }^{1}$.

The Act for the better preventing of a spurious and mixed issue refers to the representatives of different races with two names negro and mulatto and a description person of the English or other Christian nation. We can observe two forms of representation of the concept of race: 1) explicit - with the name nation, 2) implicit - in the names negro and mulatto.

... free able-bodied white male citizen" shall be enrolled in the militia (The Militia Act, 1792) ${ }^{2}$.

The Militia Act implies the concept of race in the predicate white.

In Hudgins vs. Wright, the concept of race is implied in the names negro, white and Indian.

In the case of a person visibly appearing to be a negro, the presumption is, in this country, that he is a slave, and it is incumbent on him to make out his right to freedom; but in the case of a person visibly appearing to be a white man, or an Indian, the presumption is that he is free, and it is necessary for his adversary to show that he is a slave (Hudgins vs. Wright, 1806) ${ }^{3}$.

The following fragment of Law of the United States uses a word combination persons of color, implying the concept of race in the word color:

... it shall not be lawful to employ, on board of any public or private vessels of the United States, any person or persons except citizens of the United States, or persons of color (Law of the United States, 1813) ${ }^{4}$.

In Dred Scott v. Sandford, there is an interpretation equation race $=$ ancestry:

People of African ancestry ... are not included, and were not intended to be included, under the word "citizens" in the Constitution (Dred Scott v. Sandford, 1857) ${ }^{5}$.

Along with ancestry, the decision mentions race followed by several predicates referred to representatives of the negro race which shows evidence of Discourse of Differences in that historical period:

[There] are two clauses in the Constitution which point directly and specifically to the negro race as a separate class of persons ...

The unhappy black race were separate from white by indelible marks ...

${ }^{1}$ URL: http://www.pbs.org/wgbh/aia/part4/4h2933t.html (accessed 12 March 2017).

2 URL: http://civilrights.findlaw.com/civil-rights-overview/civil-rights-lawand-history.html (accessed 1 April 2017).

3 URL: https://digitalarchive.wm.edu/handle/10288/16635 (accessed 12.04.2017).

${ }^{4}$ URL: http://www.pbs.org/wgbh/aia/part4/4h2933t.html (accessed 12 March 2017).

http://www.pbs.org/wgbh/aia/part4/4h2933t.html (accessed 12 March 2017).

5 URL: https://www.law.cornell.edu/supremecourt/text/60/393 (accessed 2 March 2017).
... in no part of the country except Maine, did the African race, in point of fact, participate equally with the whites in the exercise of civil and political rights (Dred Scott v. Sandford, $1857)^{6}$.

The Naturalization Act lacks race, it is understood to be synonymous with the terms nativity and descent:

That the naturalization laws are hereby extended to aliens of African nativity and to persons of African descent (The Naturalization Act, 1870) ${ }^{7}$.

In Plessy vs. Fergusson, race is used along with the term color. The conjunction or being as a connector of alternative allows for the conclusion about synonymous nature of these lexical units.

... he insisted upon going into a coach used by the race to which he did not belong. Neither in the information nor plea was his particular race or color averred (Plessy vs. Fergusson, 1896) ${ }^{8}$.

\section{Let us give one more example:}

The effect of the conclusion that "white person" means a Caucasian is merely to establish a zone on one side of which are those clearly eligible, and on the other those clearly ineligible, to citizenship ... (Ozawa vs. US, 1922) ${ }^{9}$.

In Ozawa vs. US, a representative of the Caucasian race is referred to as white person. However, the interpretant of white person is specified and defined as Caucasian. The need for specification is due to the uncertainty of legal status of humans born from representatives of different races. If in XVII century, the child's status was determined by that of its mother, since XVIII century the uncertain status of children born to white slave owners and their black female slaves became a legal dilemma: whether children got by an Englishman upon a negro woman should be slave or free. The states determined whether or not an individual was Black either by visual indicators or by ancestry, that is, by the "fraction" of black blood found in one's bloodline. Many states classified as "'Negro" those who were at least oneeighth Black or had at least one Black great-grandparent [ibid., p. 1114]. Other states considered only those who were one fourth or more Black to be Negro, and still others utilized onesixteenth or one-thirty-second rules. A person could, therefore, be considered White in one state and Black in another.

Thus, the concept of race in American legal discourse of the XVIII - XX centuries lacked united characteristics, had multiple interpretants which is typical for Discourse of Differences. Except for the above-mentioned terms, the concept of race was verbalized as ethnicity, culture, national origin and even religion [13, p. 1101].

\footnotetext{
${ }^{6}$ Ibid.

${ }^{7}$ URL: http://legisworks.org/sal/16/stats/STATUTE-16-Pg254a.pdf (accessed 17 February 2017).

${ }^{8}$ URL: https://www.law.cornell.edu/supremecourt/text/163/537 (accessed 19 April 2017).

9 URL: https://supreme.justia.com/cases/federal/us/260/178/case.html (accessed 12 March 2017).
} 
Transition from Discourse of Differences into Discourse of Concord is characterized by a regular use of race in American legal discourse. The name race ontologizes features limiting the notion of race from related notions - color, religion, national origin, etc.:

\section{... it is unlawful for employers:}

to fail or refuse to hire or to discharge any individual, or otherwise to discriminate against any individual with respect to his compensation, terms, conditions, or privileges of employment, because of such individual's race, color, religion, sex, or national origin ... (U.S. Civil Rights Act, 1964) ${ }^{10}$.

... refus[ing] to negotiate for the sale or rental of, or otherwise make unavailable or deny, a dwelling to any person because of race, color, religion, sex, familial status, or national origin ... (U.S.C. $\S 3604,2000)^{11}$.

The examples show that the meaning of race is not similar to the meanings of nation, color or religion. The notions have different interpretants. Race emphasizes physical characteristics, color - skin color, religion - aspects of religious observance and practice, national or ethnic origin birth nationality:

A person commits the crime of malicious harassment by intentionally threatening a specific individual and placing that individual in reasonable fear of harm because of the victim's race, color, ancestry, national origin, gender, sexual orientation, or mental, physical, or sensory handicap (State vs. Read, 2011) ${ }^{12}$.

To implement these canons, judicial review must begin from the position that "any official action that treats a person differently on account of his race or ethnic origin is inherently suspect (Fisher vs. University of Texas, 2013). ${ }^{13}$

In the first example, race is used along with color, ancestry and national origin which allows us to suggest that the Supreme Court decision differentiates between them. In the second example, the authors differentiate between race and ethnic origin.

It should be noted that in the US Constitution race is mentioned only in Amendment XV along with color. It means that the US Constitution differentiates between only two related notions verbalized by these names:

The right of citizens of the United States to vote shall not be denied or abridged by the United States or by any State on account of race, color, or previous condition of servitude (URL: http://constitution.findlaw.com/amendments.html).

Since the latter half of the $20^{\text {th }}$ century, race is used regularly in American legal discourse. New social context caused changes in conceptualization of the reality, world view of Americans, marked new Time of culture - the Civil Rights

10 URL: https://www.law.cornell.edu/uscode/text/42/2000e-2 (accessed 12 March 2017).

11 URL: https://www.law.cornell.edu/uscode/text/42/3604 (accessed 12 January 2017)

12 URL: http://caselaw.findlaw.com/wa-court-of-appeals/1580623.html) (accessed 11 February 2017).

${ }^{13}$ URL: https://www.supremecourt.gov/opinions/12pdf/11-345_15gm.pdf era. New factors of semiosis encouraged formation of the notion of race meaning a group of humans that shares certain distinctive physical traits [14]. Initially, it was used in laws aimed to prevent race discrimination. The starting point in Civil Rights era is 1964 when US Civil Rights Act was enacted. The Act ended segregation in public places and banned employment discrimination on the basis of race, color, religion, sex or national origin and caused upsurge of fighting against different forms of discrimination.

The term race is formed at the final stage of evolution of discourse practices. In different expert communities, it has different definitions. For example, in biology race is defined as genetically distinct phenotypic populations of interbreeding individuals within the same species [15], in genetics - a large population of individuals who have a significant fraction of their genes in common and can be distinguished from other races by their common gene pool [16]. In American legal discourse, the term race is defined as a set of individuals whose identity as such is distinctive in terms of physical characteristics or biological descent [17]. Variety of definitions of race in different professional settings does not raise doubts about the semiotic nature of race. The object can have a variety of definitions as it has many aspects, members of each DES emphasize those characteristics of the notion which are relevant for their discourse practices.

In modern semiosis, knowledge may develop from the term to the notion or from the notion to the concept. This is occurring to the term race which is often involved into Discourse of Differences by replacing the name race with descriptions and names allegedly lacking negative connotations: groups which have been historically discriminated against, underrepresented minorities, AfricanAmericans, Hispanics, and Native Americans:

During all relevant periods, the University has considered African-Americans, Hispanics, and Native Americans to be "underrepresented minorities ... (Gratz vs. Bollinger, 2007) ${ }^{14}$.

... "racial and ethnic diversity with special reference to the inclusion of students from groups which have been historically discriminated against, like African-Americans, Hispanics and Native Americans (Grutter vs. Bollinger, 2012) $)^{15}$.

North Carolina places heavy reliance on the fact that African-American turnout during the 2014 primary election, governed by House Bill 589, increased compared to the 2010 primary election, governed by the prior law (Ginsburg Dissenting, 2014). ${ }^{16}$

Race is considered as not only one of the most frequently misused and misunderstood words in the American vernacular; it is also a dangerous notion that can reinforce prejudice and discrimination [18]. Some authors argue that the

\footnotetext{
${ }^{14}$ URL: https://www.law.cornell.edu/supct/html/02-516.ZS.html (accessed 15 January 2017)

${ }^{15}$ URL: https://www.law.cornell.edu/supct/html/02-241.ZO.html (accessed 15 January 2017).

${ }^{16}$ URL: https://www.supremecourt.gov/opinions/14pdf/14a358_lkhn.pdf
} 
term race should not be included in statutory and jurisprudential texts [13, p. 1159].

The research revealed that race is elusive and has no reliable definition. It is not merely vague or incoherent, but worse, is a pernicious concept. Notions of race, reinforced by legal mandates, have historically engendered the belief that human beings are divided into well-defined subspecies, some of which are superior to others [19]. Negative connotations of race encourage the argument that law should discontinue use of the term race and replace it in legal discourse by more precise terminology, including ethnicity, continent of origin, ancestry, descent. Thus, in modern semiosis, one can observe devolution of the semiotic entity, regression to discourse practices of the XVIII-XIX centuries. The challenge is to find a name that captures all legally relevant connotations of the name race, a task that is most probably impossible. In searching for a fitting replacement for the name race, one might tum to ethnicity. Unfortunately, ethnicity is referred to as the fact or state of belonging to a social group that has a common national or cultural tradition [20], while race suggests classification of people by their physical characteristics. Origin is not appropriate in all circumstances. The term origin is problematic in light of ancient human history. Many scientists argue that human beings originated in Africa and that Caucasians are a subset of the population that left Africa and walked north, losing their skin pigmentation in order to adjust to colder, less sunny climates (ibid.). As a rule, the term origin refers to descendants from a country:

However, the federal government and its military leaders decided that no one of Japanese ancestry could live on the west coast of the United States, while people of Italian and German ancestry could remain (Civil Rights: Law and History) ${ }^{17}$.

Other substitutes of race are equally unsuitable which shows lack of a fitting replacement for race in all legal contexts.

As far as we can see, attempts to involve the notion of race into Discourse of Differences are manipulation technologies aimed at affecting communicants using simulacrized signs with multiple interpretants. Rejecting the explicit definition of race in legal discourse, one can manipulate the sign.

\section{CONCLUSION}

Thus, sign interpretation direction depends on intentionality of the expert community. Under specific conditions, sign interpretant may involve an unlimited number of characteristics, and the term may be used as a manipulative tool for producing Discourse of Differences - an area of manipulation.

Linguistic and semiotic analysis of legal discourse evolution allows us to emphasize one promising research issue - dialectical development from the term to the notion, or from the notion to the concept, studies on dialectical transition from one discourse practice into another one in violation of the described evolutionary scheme Discourse of Differences Discourse of Concord - Discourse of Expert Community.

The suggested mechanism of analysis of evolution of discourse practices in the legal field can serve as a basis for researches on evolutionary development of discourse practices in other fields. It can also help to follow formation of other semiotic entities which are a center of the legal system.

\section{References}

[1] M. Foucault, "The archaeology of knowledge," London and New York: Routledge, 1972, $254 \mathrm{p}$.

[2] A.M. Kaplunenko, "Concept - notion - term: evolution of semiotic entitites in the context of a discourse practice," Asian Pacific region: dialogue of cultures: Proceedings of the international conference, Irkutsk, 2007, pp. 115-120. (in Russian).

[3] O.A. Krapivkina, "Case-study of judicial TV shows," Tomsk State University Journal of Philology, vol. 46, 2017.

[4] Plato, Collected works, vol. 3. Moscow: Mysl, 1994, 654 p.

[5] Aristotle, "Politics", London: Duckworth, 1954.

[6] A.M. Kaplunenko, "Federal / Federalism: from the concept to the term. Semiotic evolution of the nomination 'Federal / Feeralism'," Vestnik of Irkutsk State Linguistic University, vol. 2(18), pp. 16-21, 2012.

[7] T.S. Kuhn, "The Structure of Scientific Revolutions," Chicago, University of Chicago Press, 1970, $210 \mathrm{p}$.

[8] V.Z. Demyankov, "Cognition and text comprehension," Issues of Cognitive Linguistics, vol. 3, pp. 5-10, 2005.

[9] P.A. Florensky, "At the rig of thought," Moscow, Akademicheskij proekt, 2012, $688 \mathrm{p}$.

[10] J. Barzun, "Race: A Study in Modern Superstition," Methuen \& Co. Ltd., 1937, $353 \mathrm{p}$.

[11] M. Batton, J. Harwood, "The race concept," Newton Abbot, David and Charles Publishers, 1975, $160 \mathrm{p}$

[12] L. Audain, "Critical Cultural Law and Economics, the Culture of Deindividualization, the Paradox of Blackness," Indiana Law Journal, , vol. 70, pp. 709-727, 1996.

[13] S. Hoffman, "Is There a place for Race as a Legal concept," Arizona State Law Journal, vol. 227, pp. 1093-1159, 1995.

[14] Merriam-Webster Collegiate Dictionary, Merriam-Webster, Inc.; 11th edition, 2003.

[15] P.M.B. Walker, The Wordsworth Dictionary of Science and Technology. Wordsworth Ed., Ltd., 1995, 1008 p.

[16] F. Vogel, A. Motulsky, "Human genetics. Problems and approaches", New York, Springer-Verlag, 1986, 807 p.

[17] 18 U.S. $\quad$ Code $\$ 1093 . \quad$ URL: https://www.law.cornell.edu/uscode/text/18/part-I/chapter-50A (accessed 23 February 2017).

[18] P.I. Rose, "They and we: racial and ethnic relations in the United States," New York, 1968, $806 \mathrm{p}$.

[19] D.L. Hutchinson, D” Progressive Race Blindness?: Individual Identity, Group Politics, and Reform," in UCLA Law Review, 2002, vol. 49, pp. 1455-1461.

[20] Oxford Dictionaries. Oxford University Press. URL: https://en.oxforddictionaries.com/definition/ethnicity (accessed 2 February 2017)

17 URL: http://civilrights.findlaw.com/civil-rights-overview/civil-rights-lawand-history.html (accessed 1 April 2017). 